Article

\title{
Impact of Control Measures on Nitrogen Oxides, Sulfur Dioxide and Particulate Matter Emissions from Coal-Fired Power Plants in Anhui Province, China
}

\author{
Haitao Dai ${ }^{1}$, Dawei Ma ${ }^{2}$, Renbin Zhu ${ }^{1, *}$, Bowen Sun ${ }^{1}$ and Jun $\mathrm{He}^{2}$ \\ 1 Anhui Province Key Laboratory of Polar Environment and Global Change, School of Earth and Space \\ Sciences, University of Science and Technology of China, Hefei 230036, China; \\ dai1994@mail.ustc.edu.cn (H.D.); sbhwlyz@mail.ustc.edu.cn (B.S.) \\ 2 State Grid Anhui Electric Power Research Institute, Hefei 230601, China; dwma@mail.ustc.edu.cn (D.M.); \\ jshqb@163.com (J.H.) \\ * Correspondence: zhurb@ustc.edu.cn; Tel.: +86-551-3606010; Fax: +86-551-63606010
}

Received: 12 December 2018; Accepted: 7 January 2019; Published: 17 January 2019

\begin{abstract}
Anhui is one of the highest provincial emitters of air pollutants in China due to its large coal consumption in coal-fired plants. In this study, the total emissions of nitrogen oxides $\left(\mathrm{NO}_{\mathrm{x}}\right)$, sulfur dioxide $\left(\mathrm{SO}_{2}\right)$ and particulate matter (PM) from coal-fired power plants in Anhui were investigated to assess the impact of control measures on the atmospheric emissions based upon continuous emission monitoring systems (CEMS). The total $\mathrm{NO}_{\mathrm{x}}, \mathrm{SO}_{2}$ and $\mathrm{PM}$ emissions significantly decreased from 2013 to 2017 and they were estimated at $24.5 \mathrm{kt}, 14.8 \mathrm{kt}$ and $3.0 \mathrm{kt}$ in 2017, respectively. The emission reductions of approximately $79.0 \%, 70.1 \%$ and $81.2 \%$ were achieved in 2017 compared with a 2013 baseline, respectively, due to the application of high-efficiency emission control measures, including the desulfurization, denitration and dust-removing devices and selective catalytic reduction (SCR). The $\mathrm{NO}_{\mathrm{x}}, \mathrm{SO}_{2}$ and $\mathrm{PM}$ emission intensities were $0.125 \mathrm{~g} \mathrm{kWh}^{-1}, 0.076 \mathrm{~g} \mathrm{kWh}^{-1}$ and $0.015 \mathrm{~g} \mathrm{kWh}^{-1}$ in 2017, respectively, which were lower than the average of national coal-fired units. The coal-fired units with $\geq 600 \mathrm{MW}$ generated $80.6 \%$ of the total electricity amount while they were estimated to account for $70.5 \%$ of total $\mathrm{NO}_{\mathrm{x}}, 70.1 \%$ of total $\mathrm{SO}_{2}$ and $71.9 \%$ of total PM. Their seasonal emissions showed a significant correlation to the power generation with the maximum correlation found in summer (July and August) and winter (January and December). The major regional contributors are the cities along the Huai River Basin and Yangtze River Basin, such as Huainan, Huaibei, Tongling, Maanshan and Wuhu, and the highest emission occurred in Huainan, accounting for approximately $26-40 \%$ of total emission from all the power plants. Our results indicated that the application of desulfurization, denitration and dust-removing devices has played an important role in controlling air pollutant emissions from coal-fired power plants.
\end{abstract}

Keywords: coal-fired power plants; CEMS; atmospheric pollutants; emission intensity; spatial and temporal variation

\section{Introduction}

The coal-fired power plants are an important industrial source for atmospheric pollutants, including nitrogen oxides $\left(\mathrm{NO}_{\mathrm{x}}\right)$, sulfur dioxide $\left(\mathrm{SO}_{2}\right)$ and particulate matter $(\mathrm{PM})$ [1-5]. It was estimated that the total amount of $\mathrm{NO}_{\mathrm{x}}, \mathrm{SO}_{2}$ and $\mathrm{PM}$ emissions from China's power plants was about $8.34 \mathrm{Tg}, 7.8 \mathrm{Tg}$ and $1.42 \mathrm{Tg}$, respectively, in 2014 [6]. To control the emissions of gaseous pollutants from coal-fired power plants, multiple policies on energy conservation and emission abatement have been implemented, including the evolution of policy instrument choice $[7,8]$, the closure of small and inefficient boilers, the improvement in techniques [9-12] and the effectiveness of national air pollution 
control policies $[4,13]$. Understanding the current status of air pollutant emissions from coal-fired power plants is vital for decision makers to assess the effectiveness of control measures and establish future regional policy [14,15].

At present, satellite observation and unit-based inventory have been widely used to estimate $\mathrm{NO}_{\mathrm{x}}$ $\mathrm{SO}_{2}$ and $\mathrm{PM}$ emissions from coal-fired power plants in China, which have indicated a recent reduction in $\mathrm{NO}_{x}$ or $\mathrm{SO}_{2}$ at a national level or for a few specific cities, such as Beijing and Shanghai [2,16-18]. The Ozone Monitoring Instrument was applied to observe the reduction in $\mathrm{SO}_{2}$ emissions from Chinese power plants from 2005 to 2007 [19]. An updated emission inventory of coal-fired power plants was developed to explore the atmospheric emissions of coal-fired power plants in Shandong in 2012 [15]. In addition, a continuous emission monitoring system (CEMS) with high resolution and accuracy has been used to study the temporal and spatial variations of $\mathrm{NO}_{\mathrm{x}}, \mathrm{SO}_{2}$ and $\mathrm{PM}$ emissions from coal-fired power [20,21]. The inclusion of the CEMS data into air quality models has led to a more accurate representation of photochemical ozone formation and annual trends while they were also used for developing a $\mathrm{CO}_{2}$ emission inventory with a high spatial and time resolution [22,23]. Previous studies have mainly concentrated on the temporal and spatial characteristics of individual pollutants based upon the detailed information of coal-fired units [24-26]. The literature seems to lack a systematic understanding of the overall emission status of major air pollutants within the power sector. Furthermore, the base year of the emissions for the coal-fired plants has primarily been 2012, 2010, 2005 or earlier $[15,27,28]$, which does not capture the influence of the latest emission control measures. During China's 12th Five Year Plan (2011-2015), the PM-removing, desulphurization and denitration devices were extensively applied in the coal-fired power plants to reduce the $\mathrm{SO}_{2}, \mathrm{NO}_{\mathrm{x}}$ and PM emissions $[8,29,30]$. The $\mathrm{SO}_{2}, \mathrm{NO}_{\mathrm{x}}$ and $\mathrm{PM}$ emission factors might change due to the application of these control technologies. However, the effectiveness of these control technologies in decreasing the emissions of gaseous pollutants from the coal-fired plants has not been assessed in detail.

Anhui Province, which is located in East China, is one of the fastest developing provinces. The coal consumption of the power sector in Anhui was 5.0-6.0 Mt in 2014, accounting for more than 50\% of total provincial coal consumption. The coal-fired power plants have caused complex and severe atmospheric pollution problems due to large consumption of coal and the concentrated distribution of coal-fired plants around the cities. The control measures for air pollutant emissions have been extensively applied in Anhui coal-fired power plants but their impact on the current emission status have not been assessed. In this paper, we choose the coal-fired power plants in Anhui Province as the study area (Figure 1) and use CEMS to continuously monitor the emissions of $\mathrm{NO}_{\mathrm{x}}, \mathrm{SO}_{2}$ and $\mathrm{PM}$ from 2013 to 2017. The objectives of this study are (1) to characterize total provincial emissions of $\mathrm{SO}_{2}, \mathrm{NO}_{\mathrm{x}}$ and PM from coal-fired power plants in Anhui; (2) to investigate the temporal and spatial variability in provincial $\mathrm{SO}_{2}, \mathrm{NO}_{x}$ and PM emissions; and (3) to evaluate the influence of current control measures on $\mathrm{SO}_{2}, \mathrm{NO}_{\mathrm{x}}$ and $\mathrm{PM}$ emissions. 


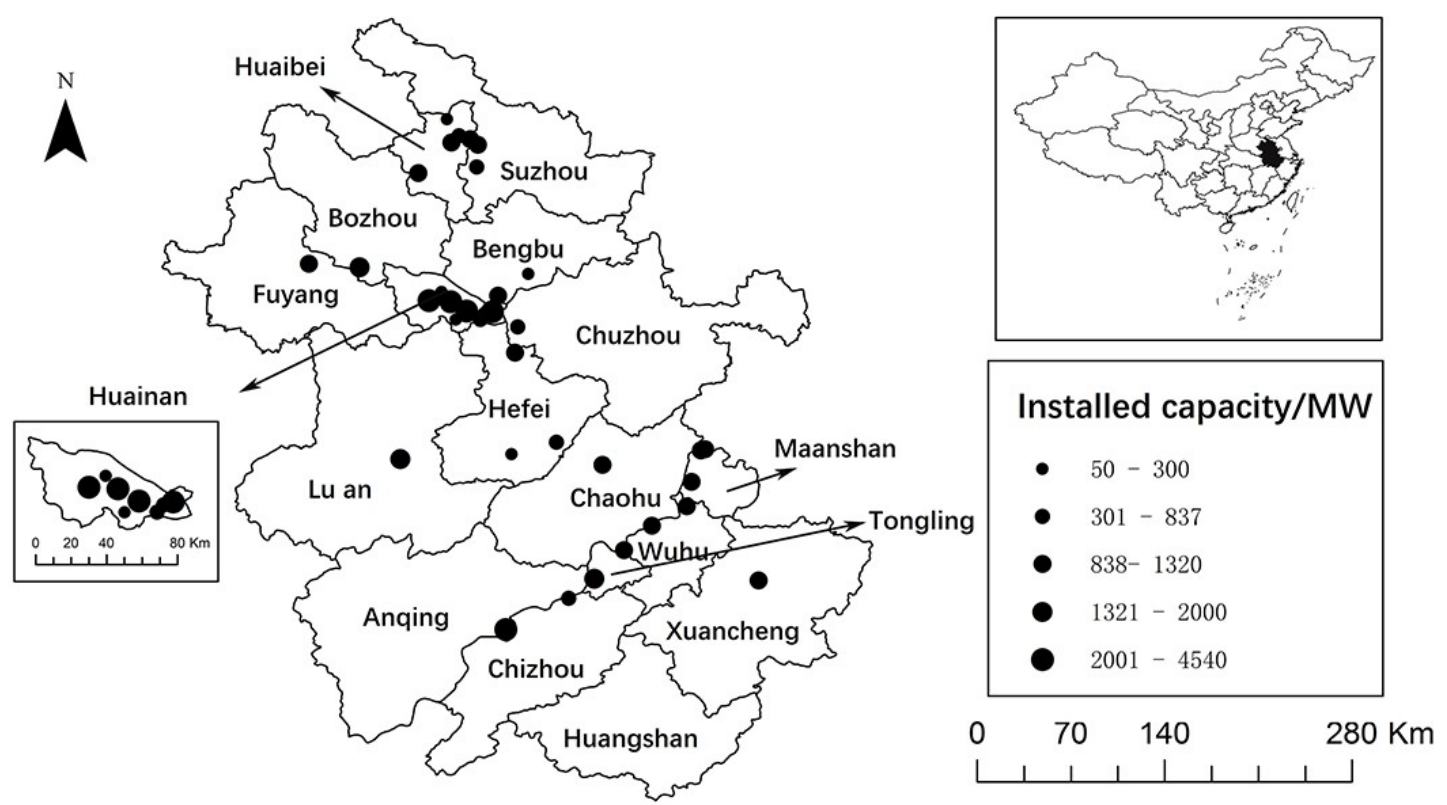

Figure 1. Study area and location of major coal-fired power plants in Anhui Province. The power plants around Huainan City are separately shown on the left of the map due to the dense distribution of coal-fired plants. The maps were drawn using ArcMap 10.2.

\section{Data and Methods}

\subsection{Study Area}

Anhui Province is located at approximately $114^{\circ} 54^{\prime}-119^{\circ} 37^{\prime} \mathrm{E}$ and $29^{\circ} 41^{\prime}-34^{\circ} 36^{\prime} \mathrm{N}$, covering a total area of $140,100 \mathrm{~km}^{2}$. Furthermore, it covers an area that is $450 \mathrm{~km}$ long from the east to the west and about $570 \mathrm{~km}$ long from the north to the south. The province can be roughly divided into five natural areas: the Huaibei Plain, the Jianghuai Hills, the Dabie Mountains in the west, the plains along the Yangtze River and the mountains in the south. The annual mean temperature is $14-17^{\circ} \mathrm{C}$ and the mean precipitation is $773-1670 \mathrm{~mm}$. It was estimated that the population of Anhui Province was 62.548 million in 2017. Coal and power are the main industries in Anhui Province and 16 cities of all 17 cities contain power plants. Most coal-fired power plants are located in Huainan City and Huaibei City while in other cities, one or two power plants are generally distributed in each city. In this study, 35 coal-fired power plants were investigated, which were mainly distributed along the Huai River and Yangtze River, as shown in Figure 1. The coal-fired power plants in Huainan City accounted for $31.3 \%$ of the total provincial installed capacity. All the power plants increased unit capacity in 2013 and 2015 with the growth rates of $19.8 \%$ and $21.3 \%$, respectively. More than 50 ultra-supercritical units of $\geq 600$ MW have been established in Anhui since 2017, accounting for $71.8 \%$ of the total installed capacity, and the power generation has increased to $195.02 \mathrm{GWh}$, as shown in Supplementary Materials Table S1. The corresponding control technologies, including flue gas desulfurization (FGD), denitration, selective catalytic reduction (SCR) systems and PM removal devices, have also been used in almost all the power plants.

\subsection{Measurements of $\mathrm{NO}_{x}, \mathrm{SO}_{2}$ and $\mathrm{PM}$ Concentrations}

The continuous emissions monitoring system (CEMS) was designed to provide direct, real-time, continuous measurements of $\mathrm{NO}_{x}, \mathrm{SO}_{2}$ and $\mathrm{PM}$ concentrations by analyzing representative samples of the flue gas. This system has been installed in most of coal-fired power plants in Anhui Province. The CEMS system consists of the master stations in the provincial dispatch center and the sub-stations in power plants. Monthly data can be downloaded at the boiler/stack unit level rather than for each 
monitoring location. Power plants with separate units, which can use different fuels, and have different types of pollution control technology, are included as separate entries in the database. The data are transmitted from the sub-station to the master station in the provincial dispatch center. The Ministry of Environment Protection (MEP) has issued several CEMS-related technical guidelines and management rules over the past decade to ensure the data quality [11]. These technical specifications and orders shown in Supplementary Materials Table S2 were developed to guide and standardize CEMS installation, certification, operation and maintenance. The Environmental Protection bureaus (EPBs) used the normal procedures to conduct the tests for the CEMS. Therefore, CEMS can provide accurate and consistent data for assessing compliance with emission control requirements [31,32].

\subsection{CEMS Validation Using MRU NOVA2000 Flue Gas Analyzer}

The reference tests were conducted at least once every six months in most of coal-fired power plants to ensure data quality. MRU NOVA2000 flue gas analyzer was used to measure the concentrations of $\mathrm{NO}_{\mathrm{x}}, \mathrm{SO}_{2}$ and PM in the inlet and outlet of FGD and SCR systems. According to the grid method [33], the testing sites for the $\mathrm{SO}_{2}$ and $\mathrm{PM}$ concentrations were located at the inlet and outlet of the flue gas desulfurization tower, respectively. The testing sites for $\mathrm{NO}_{\mathrm{x}}$ concentrations were at the inlet and outlet of each $\mathrm{SCR}$ reactor for the denitration systems. The $\mathrm{NO}_{\mathrm{x}}$ and $\mathrm{SO}_{2}$ concentrations were measured from 20 and 21 plants in 2013 and 2014, respectively, and PM emissions were measured from 25 plants in 2014. All testing instruments were subjected to metrological certification and calibration. The molar ratios of $\mathrm{SO}_{2}$ to $\mathrm{NO}_{\mathrm{x}}$, i.e., $\mathrm{SO}_{2} / \mathrm{NO}_{\mathrm{x}}$ obtained using CEMS and MRU NOVA2000 flue gas analyzer, were compared to validate the validity of the data from the coal-fired power plants.

\subsection{Statistical Analyses}

Statistical analyses were conducted using OriginPro 2018, SPSS 20.0 and Microsoft Excel for Windows 2016. For each emission of $\mathrm{NO}_{\mathrm{x}}, \mathrm{SO}_{2}$ and $\mathrm{PM}$, the standard error (SE) was used to estimate the uncertainty. The differences between $\mathrm{NO}_{\mathrm{x}}, \mathrm{SO}_{2}$ and $\mathrm{PM}$ concentrations from CEMS and MRU NOVA2000 were tested using the paired-sample t-test. Correlations between $\mathrm{NO}_{\mathrm{x}}, \mathrm{SO}_{2}$ and $\mathrm{PM}$ concentrations were determined using Pearson correlation analysis. We used the concentrations of $\mathrm{NO}_{\mathrm{x}}, \mathrm{SO}_{2}$ and $\mathrm{PM}$ measured by CEMS to estimate the emissions of three air pollutants from coal-fired power plants. First, annual average concentrations of $\mathrm{NO}_{\mathrm{x}}, \mathrm{SO}_{2}$ and $\mathrm{PM}$ were calculated based on the CEMS data. According to the low calorific value data of each coal-fired power plants, the theoretical dry flue gas volume was calculated in each coal-fired unit. After this, the emission factors were obtained in each CEMS unit, which were combined with the theoretical dry flue gas volume and emission concentrations. Finally, based on the emission factor method, the emissions of air pollutants from each CEMS power plants were calculated from the bottom to up. The types of fuel used in power plants in Anhui were mainly bituminous coal and anthracite. The specific formulas are as follows:

$$
\begin{gathered}
\mathrm{Em}=\sum_{n} A C_{n} \times E F_{n} \\
C_{A V G, n}=\sum_{j} \sum_{h} C_{j, h} / \sum_{j} O p h_{j} \\
E F_{n}=C_{A V G, n} \times V_{n} \\
\mathrm{~V}=1.04 \times Q_{L} / 4186.8+0.77+1.0161 \times(\alpha-1) \times V_{0} \\
V_{0}=0.251 \times Q_{L} / 1000+0.278 \text { (Bituminous) } \\
V_{0}=Q_{L} / 4140+0.606 \text { (Anthracite) }
\end{gathered}
$$

where $h, j$, and $n$ stand for the operating hour, exhaust vent number, different power plants, respectively;

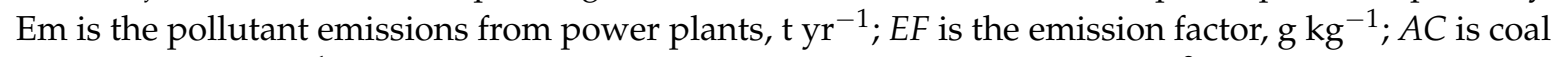
consumption, $\mathrm{t} \mathrm{yr}^{-1} ; C_{A V G}$ is the statistical mean gas concentration, $\mathrm{mg} \mathrm{m}^{-3} ; C_{j}$ is hourly mean gas 
concentration of exhaust vent from CEMS; Oph is number of monitoring hours; $V$ is the theoretical amount of exhaust, $\mathrm{m}^{3} \mathrm{~kg}^{-1} ; Q_{L}$ is the low calorific value of coal burning, $\mathrm{kJ} \mathrm{kg}^{-1} ; \alpha$ is the excess air coefficient with the ratio 1.4 in this study; and $V_{0}$ is the theoretical air volume [3,34]. The $Q_{L}$ value for different types of coals were obtained from statistics [35].

We estimated the contribution (i.e., the percentage of the total emissions) of the desulphurization and denitration devices to the decrease in the $\mathrm{NO}_{\mathrm{x}}, \mathrm{SO}_{2}$ and $\mathrm{PM}$ emissions from coal-fired power plants. The decrease in $\mathrm{NO}_{\mathrm{x}}, \mathrm{SO}_{2}$ and $\mathrm{PM}$ emissions during the period from 2014 to 2017 was calculated relative to the baseline emissions for 2013 using the following formulas:

$$
\begin{aligned}
& \Delta_{\text {emission }, t}=E G_{t} \times\left(E I_{2013}-E I_{t}\right) \\
& \% \Delta_{t}=\Delta_{\text {emission }, t} /\left(E G_{t} \times E I_{2013}\right)
\end{aligned}
$$

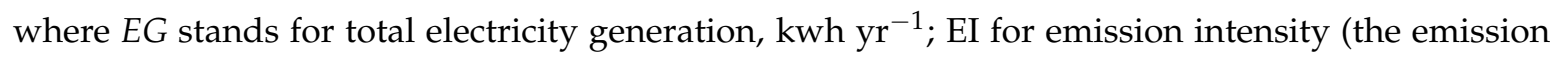
amount per $\mathrm{kW} \mathrm{h}), \mathrm{g} \mathrm{kWh}{ }^{-1}, \mathrm{t}$ for the year; and $\% \Delta$ for the percentage of the emission reduction.

\section{Results and Discussion}

\subsection{CEMS Validation}

The molar ratios of $\mathrm{SO}_{2}$ to $\mathrm{NO}_{\mathrm{x}}\left(\mathrm{SO}_{2} / \mathrm{NO}_{\mathrm{x}}\right)$ obtained through CEMS and MRU NOVA2000 are illustrated in Figure 2. The $\mathrm{NO}_{x}$ and $\mathrm{SO}_{2}$ concentrations from CEMS had a total $2 \sigma$ uncertainty $( \pm 21 \%)$. The uncertainty for the slope of $\mathrm{SO}_{2}$ versus $\mathrm{NO}_{x}$ linear correlation was estimated to be $\pm 28 \%(2 \sigma)$ from the MRU NOVA2000. The molar ratios of $\mathrm{SO}_{2}$ to $\mathrm{NO}_{\mathrm{x}}$ from the MRU NOVA2000 and CEMS were consistent and they were within the combined uncertainty of $\pm 41 \%$. The PM concentrations from CEMS and MRU NOVA2000 were also compared. Although the PM concentrations from CEMS showed a larger fluctuation than those from the MRU NOVA2000, they were within the error range, as shown in Figure 2c. No significant differences were found between the ratios of $\mathrm{SO}_{2}$ to $\mathrm{NO}_{\mathrm{x}}$ for 2013 $(\mathrm{t}=0.319, p=0.754)$ and $2014(\mathrm{t}=0.043, p=0.966)$ and between PM concentrations $(\mathrm{t}=0.689, p=0.498)$. Furthermore, significant correlations were obtained between the molar ratios of $\mathrm{SO}_{2}$ to $\mathrm{NO}_{\mathrm{x}}(\mathrm{r}=0.96$, $p<0.01)$ and between PM concentrations $(\mathrm{r}=0.80, p<0.01)$, which is shown in Table 1 . Therefore, the CEMS data were found to accurately reflect $\mathrm{SO}_{2}, \mathrm{NO}_{\mathrm{x}}$ and $\mathrm{PM}$ concentrations from the coal-fired power plants.

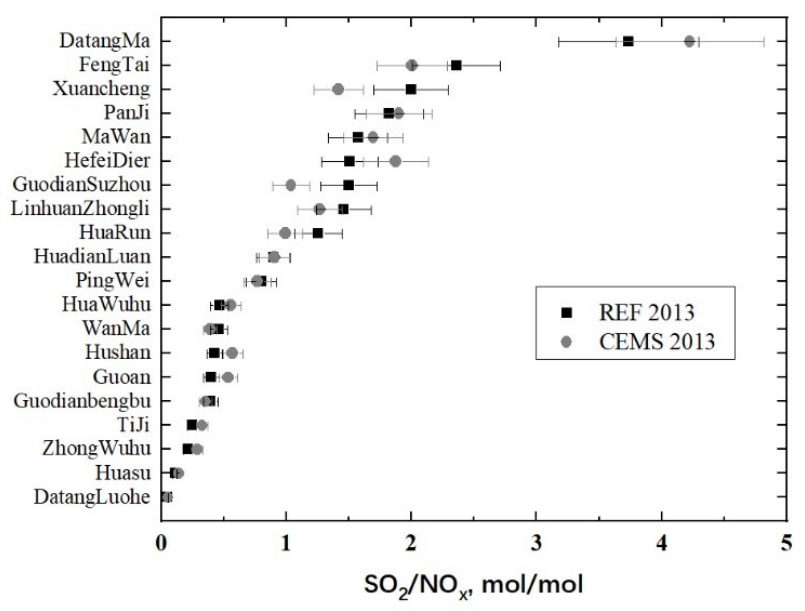

(a)

Figure 2. Cont. 


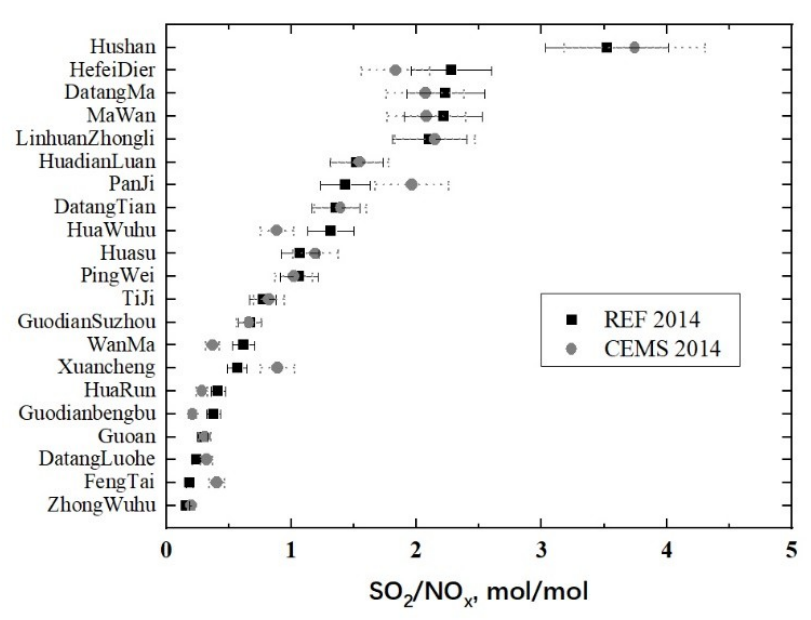

(b)

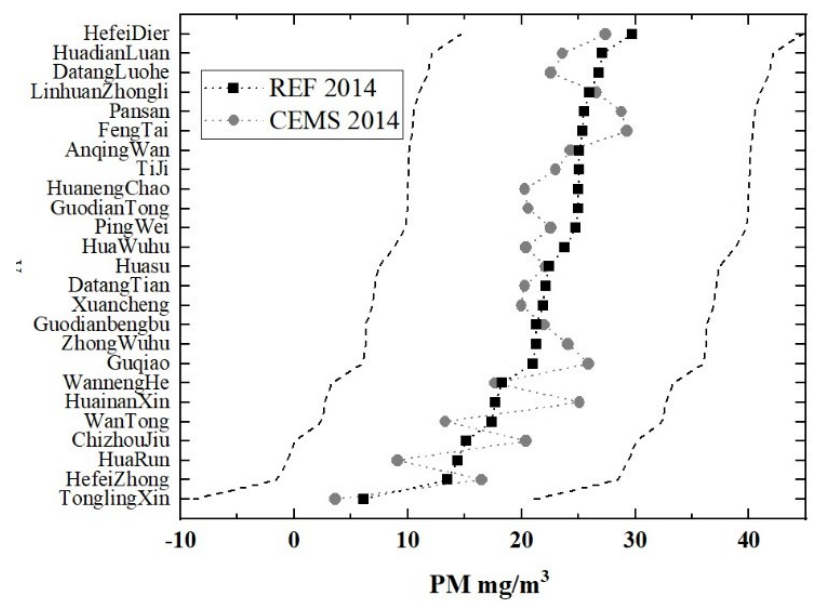

(c)

Figure 2. CEMS validation using reference test. $(\mathbf{a}, \mathbf{b})$ comparisons of $\mathrm{SO}_{2} / \mathrm{NO}_{\mathrm{x}}$ mole ratios obtained using MRU NOVA2000 (black squares) and CEMS (grey dots) in 2013 and 2014. Bars on CEMS data are $\pm 30 \%(2 \sigma)$ combined uncertainties. Bars on MRU NOVA2000 measurements are the $\pm 28 \%(2 \sigma)$ combined uncertainties. (c) comparisons of PM concentration measured by MRU NOVA2000 (black squares) and CEMS (grey dots) in 2014. Data are arranged in the order of decreasing MRU NOVA2000 PM emission. The dotted line represents the allowable range of error, which is the value measured by MRU NOVA2000 plus or minus $15 \mathrm{mg} \mathrm{m}^{-3}$.

Table 1. The paired $t$-test and correlation coefficients between $\mathrm{SO}_{2} / \mathrm{NO}_{\mathrm{x}}$ and $\mathrm{PM}$ concentrations obtained through CEMS and MRU NOVA2000.

\begin{tabular}{cccc}
\hline & $\mathbf{2 0 1 3} \mathbf{S O}_{2} / \mathbf{N O}_{\mathbf{x}}$ & $\mathbf{2 0 1 4} \mathbf{S O}_{\mathbf{2}} / \mathbf{N O}_{\mathbf{x}}$ & $\mathbf{2 0 1 4} \mathbf{P M}$ \\
\hline Paired-sample T-test & 0.754 & 0.966 & 0.498 \\
correlation coefficient & $0.964^{* *}$ & $0.967^{* *}$ & $0.802^{* *}$ \\
\hline \multicolumn{4}{c}{$p<0.01}$.
\end{tabular}

\section{2. $\mathrm{NO}_{x}, \mathrm{SO}_{2}$ and PM Emissions from Coal-Fired Power Plants under Control Measures}

The $\mathrm{NO}_{\mathrm{x}}, \mathrm{SO}_{2}$ and $\mathrm{PM}$ emission intensity and annual total emissions significantly decreased from 2013 to 2017 due to the large-scale application of denitration technologies, desulfurization measures and PM-removing devices. Figure 3 a shows that the $\mathrm{NO}_{\mathrm{x}}, \mathrm{SO}_{2}$ and $\mathrm{PM}$ emissions in 2017 decreased by about $79.0 \%, 70.1 \%$ and $81.2 \%$ relative to the baseline emissions in 2013 . The emission intensity 
decreased from $0.69 \mathrm{~g} \mathrm{kWh}^{-1}$ to $0.13 \mathrm{~g} \mathrm{kWh}^{-1}$; from $0.29 \mathrm{~g} \mathrm{kWh}^{-1}$ to $0.08 \mathrm{~g} \mathrm{kWh}^{-1}$; and from $0.098 \mathrm{~g} \mathrm{kWh}^{-1}$ to $0.015 \mathrm{~g} \mathrm{kWh}^{-1}$, respectively. The $\mathrm{NO}_{\mathrm{x}}, \mathrm{SO}_{2}$ and $\mathrm{PM}$ emission intensities were $0.36 \mathrm{~g} \mathrm{kWh}^{-1}, 0.39 \mathrm{~g} \mathrm{kWh}^{-1}$ and $0.08 \mathrm{~g} \mathrm{kWh}^{-1}$, respectively, at the national level in 2016. These are higher than those from the coal-fired power units in Anhui Province [6].

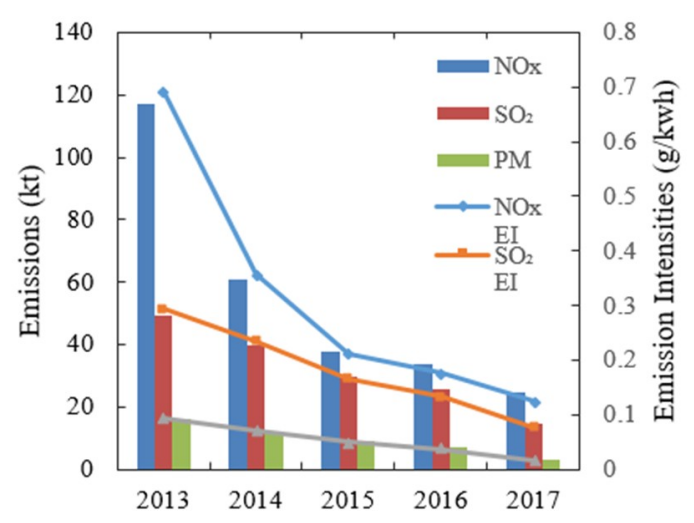

(a)

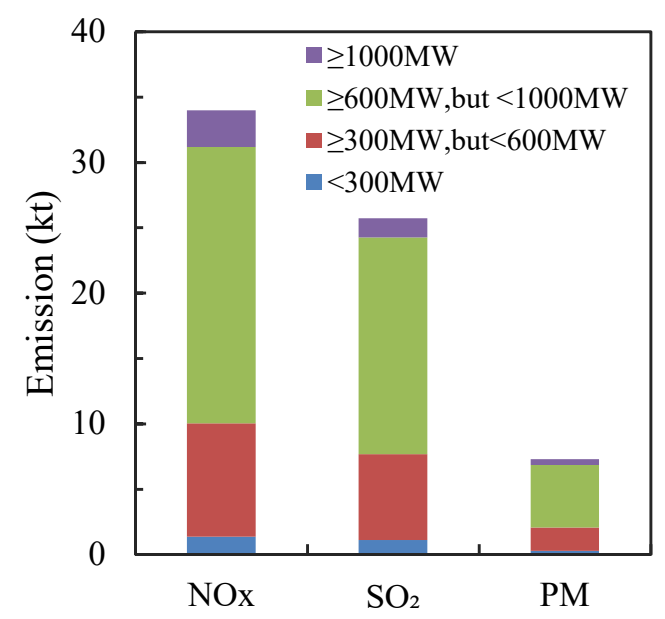

(b)

Figure 3. $\mathrm{NO}_{\mathrm{x}}, \mathrm{SO}_{2}$ and $\mathrm{PM}$ emissions from coal-fired power plants in Anhui Province. (a) Annual emissions of $\mathrm{NO}_{\mathrm{x}}, \mathrm{SO}_{2}$ and $\mathrm{PM}$ and their emission intensities (EI) from coal-fired power plants between 2013 and 2017; (b) Emission inventory of different unit groups in Anhui in 2016.

The $\mathrm{SO}_{2}, \mathrm{NO}_{\mathrm{x}}$ and $\mathrm{PM}$ emissions in 2016 were estimated according to the unit capacity for coal-fired power plants, which is shown in Figure 3b. Overall, the coal-fired units with $\geq 600 \mathrm{MW}$ generated $80.6 \%$ of total electricity amount and they emitted $23.9 \mathrm{kt} \mathrm{NO}_{\mathrm{x}}, 18.0 \mathrm{kt} \mathrm{SO}$ and $5.2 \mathrm{kt}$ $\mathrm{PM}$, accounting for $70.5 \%$ of total $\mathrm{NO}_{\mathrm{x}}, 70.1 \%$ of total $\mathrm{SO}_{2}$ and $71.9 \%$ of total PM. Their emission intensities and consumed coal per $\mathrm{kWh}$ all decreased with the unit capacity shown in Table 2, which was in accordance with previous studies [6,30]. The $\mathrm{NO}_{x}$ and $\mathrm{SO}_{2}$ emission intensities from the units ( $\geq 600 \mathrm{MW}$ ) were 0.18 and $0.13 \mathrm{~g} \mathrm{kWh}^{-1}$, respectively, accounting for about $60 \%$ from the units $(<300 \mathrm{MW})$, whereas the PM emission intensity from the units $(\geq 600 \mathrm{MW})$ was only $0.04 \mathrm{~g} \mathrm{kWh}^{-1}$, accounting for about $70 \%$ from the units $(<300 \mathrm{MW})$. Our results indicated that the introduction of large and highly efficient units as well as the large-scale application of denitration technologies, desulfurization measures and PM-removing device have greatly decreased the consumed coal per $\mathrm{kWh}$ and $\mathrm{NO}_{\mathrm{x}}, \mathrm{SO}_{2}$ and $\mathrm{PM}$ emissions from coal-fired power plants in Anhui Province. 
Table 2. Emission intensities and consumed coal per kWh for different unit groups in Anhui Province in 2016.

\begin{tabular}{|c|c|c|c|c|}
\hline \multirow{2}{*}{ Unit Capacity (UC) } & $\mathrm{SO}_{2}$ & $\mathrm{NO}_{\mathbf{x}}$ & PM & \multirow{2}{*}{ 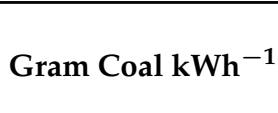 } \\
\hline & \multicolumn{3}{|c|}{ Emission Intensities $\left(\mathrm{g} \mathrm{kWh}^{-1}\right)$} & \\
\hline $\mathrm{UC}<300 \mathrm{MW}$ & 0.228 & 0.285 & 0.053 & 321.2 \\
\hline $300 \leq \mathrm{UC}<600 \mathrm{MW}$ & 0.177 & 0.234 & 0.048 & 312.1 \\
\hline $600 \leq \mathrm{UC}<1000 \mathrm{MW}$ & 0.107 & 0.137 & 0.031 & 298.4 \\
\hline $\mathrm{UC} \geq 1000 \mathrm{MW}$ & 0.063 & 0.120 & 0.019 & 278.3 \\
\hline
\end{tabular}

\subsection{Temporal Variations of $\mathrm{NO}_{x}, \mathrm{SO}_{2}$ and PM Emissions from Coal-Fired Power Plants}

The annual or monthly amount of generated electricity increased from 2013 to 2017, but the annual or monthly $\mathrm{NO}_{\mathrm{x}}, \mathrm{SO}_{2}, \mathrm{PM}$ emissions decreased with all the seasonal emission peaks in the summer months of July and August and in the winter months of January and December, as shown in Figure 4. During the period from October in 2013 to May in 2014, the total $\mathrm{NO}_{\mathrm{x}}$ emissions showed a sharp decline following the completion of the denitration transformation in most of the coal-fired plant units. Significantly higher $\mathrm{SO}_{2}$ and PM emissions occurred in July and August of 2013 due to the enhanced power generation. The coal-fired power plants in Anhui had completed the installation of PM removing and desulphurization devices during the 11th $\mathrm{FYP}$ and the $\mathrm{SO}_{2}$ and $\mathrm{PM}$ emissions decreased gradually with the improvement in the desulphurization and PM removal efficiency in most power plants during the 12th FYP [36]. Similarly, the $\mathrm{SO}_{2}$ and PM emissions also reached their peak in summer and winter following the power generation. Overall, the $\mathrm{NO}_{\mathrm{x}}, \mathrm{SO}_{2}$ and $\mathrm{PM}$ emissions and power generation showed significant positive correlation $(P<0.05)$ after the application of control measures, indicating that their seasonal emissions were significantly affected by power generation from 2013 to 2017 (Table 3).
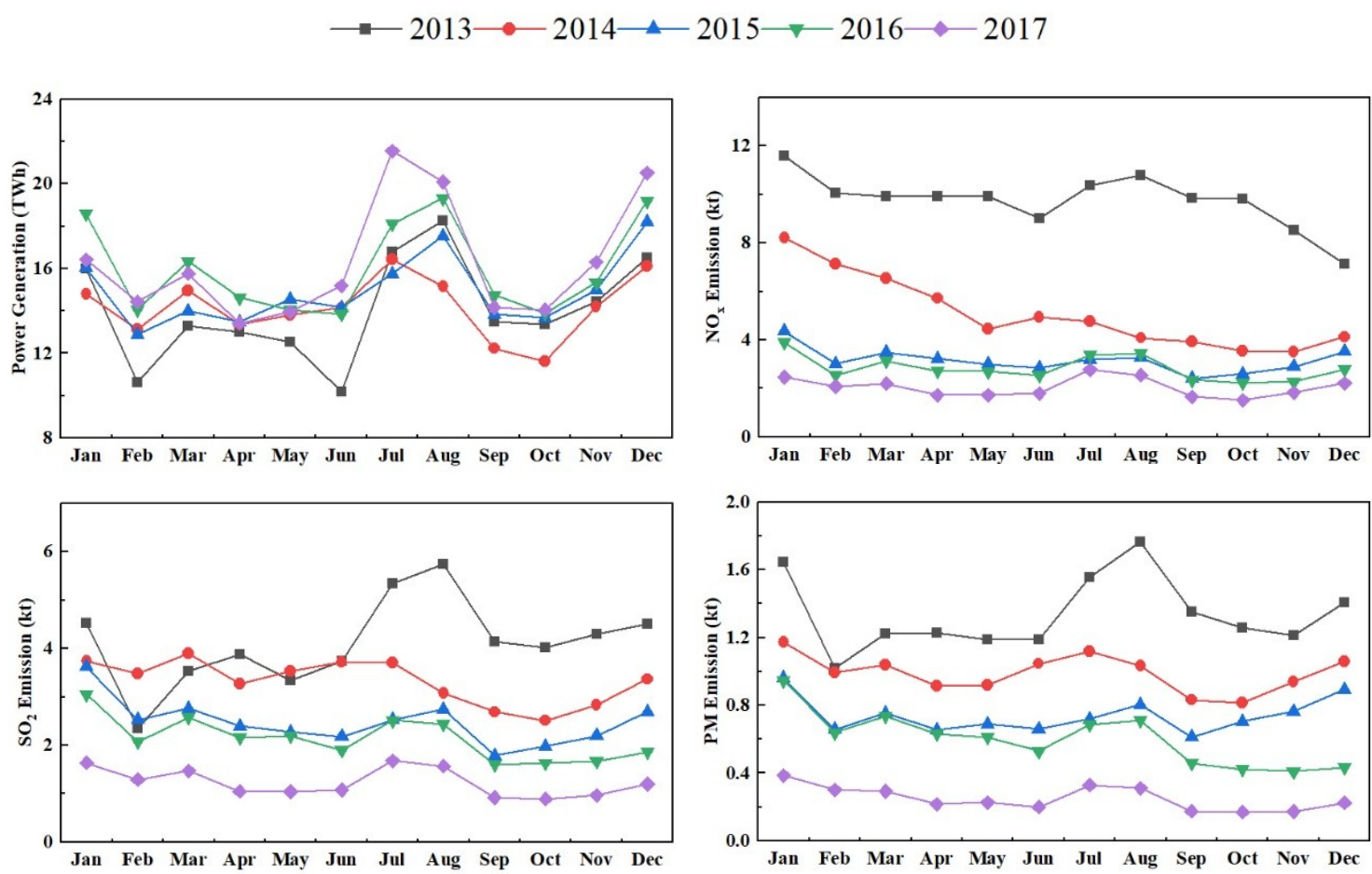

Figure 4. Monthly variations of power generation and $\mathrm{NO}_{\mathrm{x}}, \mathrm{SO}_{2}$ and $\mathrm{PM}$ emissions from coal-fired power plants in Anhui Province between 2013 and 2017. 
Table 3. Correlations between air pollutant emissions and power generation from 2013 to 2017.

\begin{tabular}{cccccc}
\hline \multicolumn{7}{c}{$\mathbf{2 0 1 3}$} & $\mathbf{2 0 1 4}$ & $\mathbf{2 0 1 5}$ & $\mathbf{2 0 1 6}$ & $\mathbf{2 0 1 7}$ \\
\hline \multicolumn{5}{c}{ Determination coefficient $\left(\mathrm{R}^{2}\right)$} \\
\hline $\mathrm{NO}_{\mathrm{x}}$ & 0.13 & 0.14 & 0.50 & $0.77^{* *}$ & $0.824^{* *}$ \\
$\mathrm{SO}_{2}$ & $0.89^{*}$ & $0.63^{*}$ & 0.48 & 0.56 & $0.65^{*}$ \\
$\mathrm{PM}$ & $0.89^{* *}$ & $0.84^{* *}$ & $0.77^{* *}$ & 0.42 & 0.44 \\
\hline \multicolumn{5}{c}{$*<0.05,{ }^{* *} p<0.01}$.
\end{tabular}

It was noted that the highest $\mathrm{NO}_{\mathrm{x}}, \mathrm{SO}_{2}$ and $\mathrm{PM}$ emissions from coal-fired power plants occurred in winter, which might lead to serious air pollution during the wintertime. In recent years, heavy haze events have taken place in some cities of North China due to the excessive emission of air pollutants [37]. $\mathrm{NO}_{x}, \mathrm{SO}_{2}$ and $\mathrm{PM}$ emissions from coal-fired power plants might be an important contributor to the production of heavy haze $[38,39]$. The corresponding policies along with the control measures should be carried out to further decrease these air pollutant emissions from coal-fired power plants in winter.

\subsection{Spatial Variations of $\mathrm{NO}_{x}, \mathrm{SO}_{2}$ and $\mathrm{PM}$ Emissions from Coal-Fired Power Plants}

The $\mathrm{NO}_{\mathrm{x}}, \mathrm{SO}_{2}$ and $\mathrm{PM}$ emissions have been assigned to the corresponding grid cells based on the longitudes and latitudes according to the CEMS data from 2013 to 2017 at the unit levels shown in Figure 5. The three air pollutant emissions from almost all the coal-fired power plant units in Anhui decreased from 2013 to 2017 with the largest decrease in $\mathrm{NO}_{\mathrm{x}}$ emission. In 2013, there were 16 and 20 units that emitted over $3 \mathrm{kt}$ of $\mathrm{NO}_{\mathrm{x}}$ and $1 \mathrm{kt}$ of $\mathrm{SO}_{2}$ each while the total $\mathrm{NO}_{\mathrm{x}}$ and $\mathrm{SO}_{2}$ emissions were $87.8 \mathrm{kt}$ and $44.3 \mathrm{kt}$. In contrast, the number of units that emitted over $3 \mathrm{kt}$ of $\mathrm{NO}_{\mathrm{x}}$ and $1 \mathrm{kt}$ of $\mathrm{SO}_{2}$ was 0 and 2, respectively, in 2017. The emissions from the units that emitted more than $0.1 \mathrm{kt} P \mathrm{PM}$ accounted for $99.8 \%$ of the total emissions in 2013 and $51.0 \%$ in 2017.

The Huai River Basin and Yangtze River Basin was found to have the highest emission density for $\mathrm{NO}_{\mathrm{x}}, \mathrm{SO}_{2}$ and $\mathrm{PM}$ from coal-fired units. The two northern cities of Huainan and Huaibei stood out as the largest three coal-fired emission sources, which is most likely attributed to the abundant water resource and large consumption of coal as a power source [40]. The highest emissions occurred in Huainan that covers only $4 \%$ of the provincial area as it accounted for $26-40 \%$ of the total emissions. The three southern cities of Tongling, Maanshan and Wuhu also had high emissions, which might be due to their rapidly developing economies and increasing power demands. Serious air pollution still occurred in the cities of Huainan, Huaibei and Maanshan, Wuhu and Tongling from 2013 to 2017, although the total air pollutant emissions from coal-fired power plants decreased due to the control measures [41]. Therefore, the spatial distribution of emissions has illuminated the need for more attention and more stringent regional policy in the Huai River Basin and Yangtze River Basin of Anhui in order to further control the pollutant emissions from coal-fired power plants. 

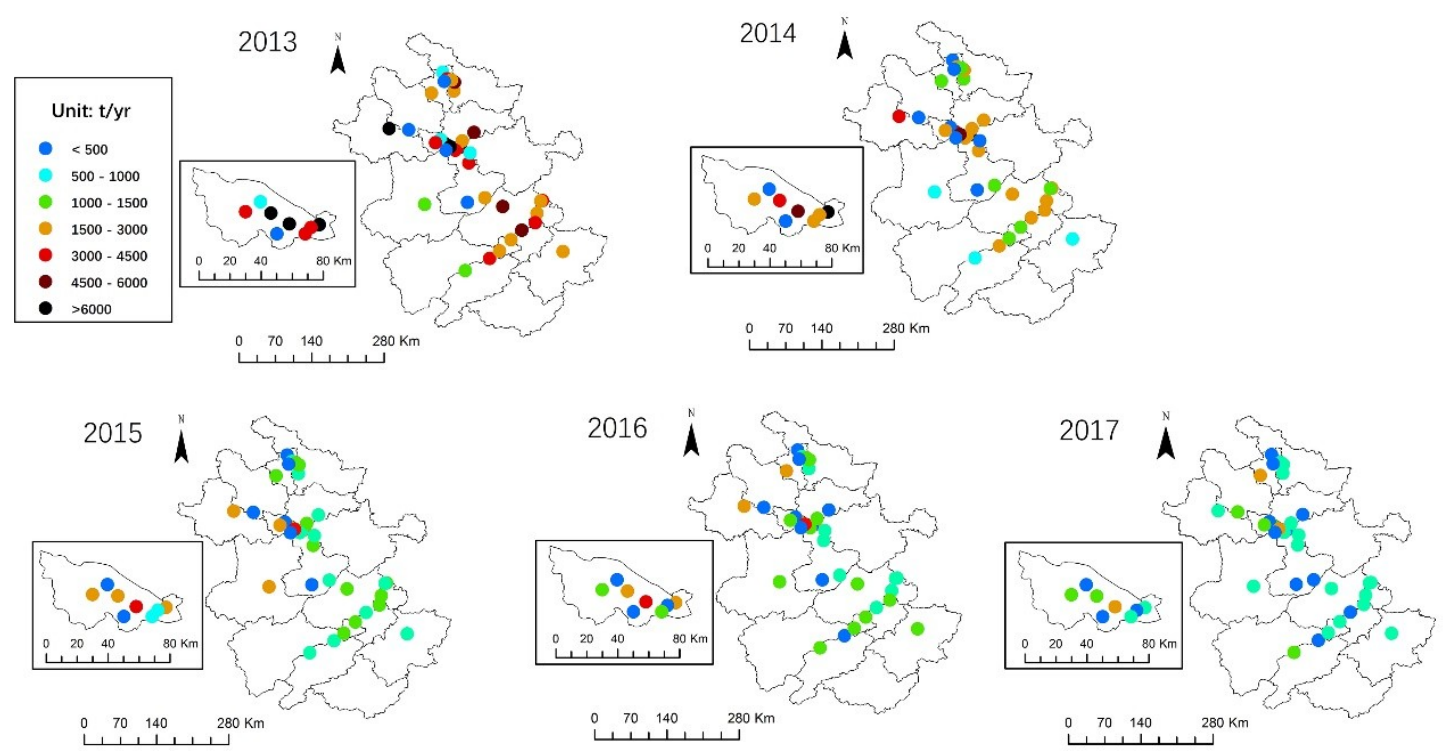

(a) $\mathrm{NO}_{x}$ emissions
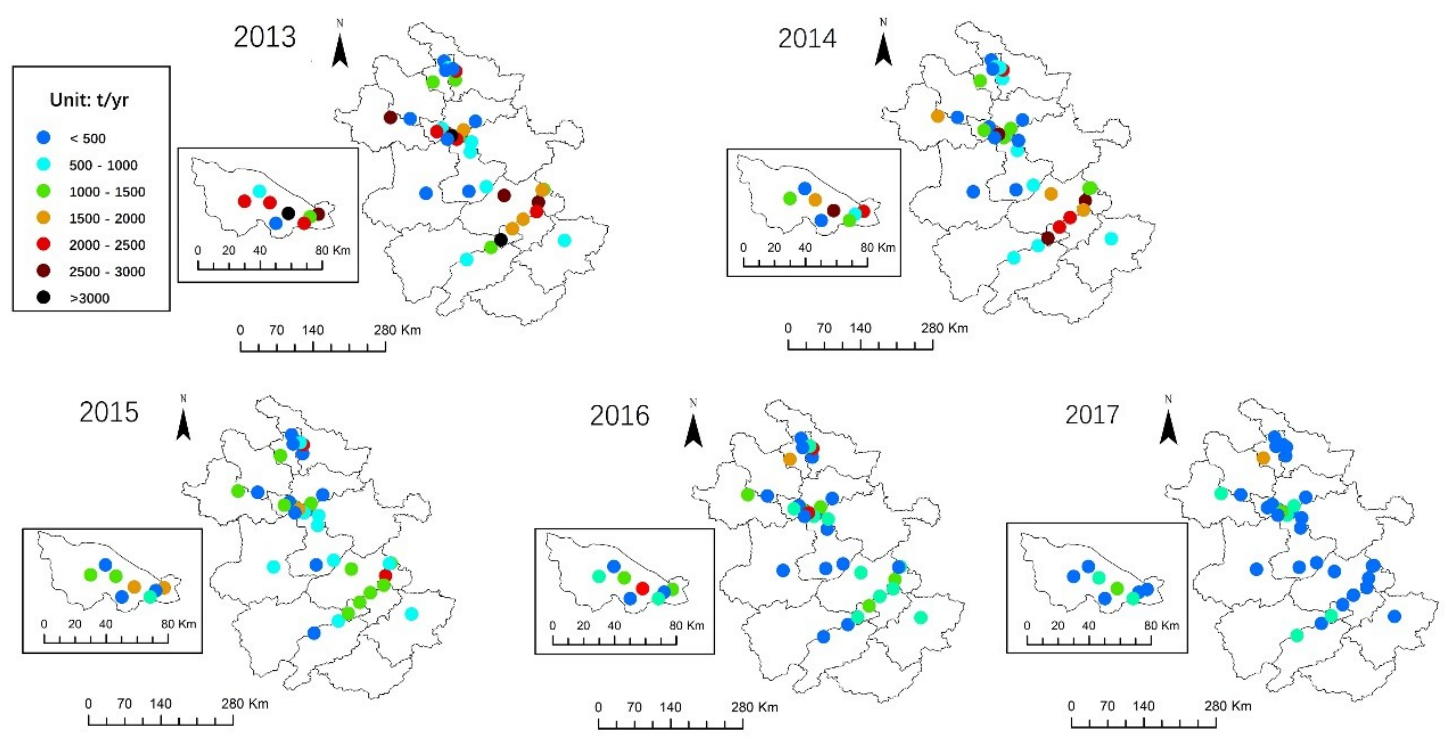

(b) $\mathrm{SO}_{2}$ emissions

Figure 5. Cont. 

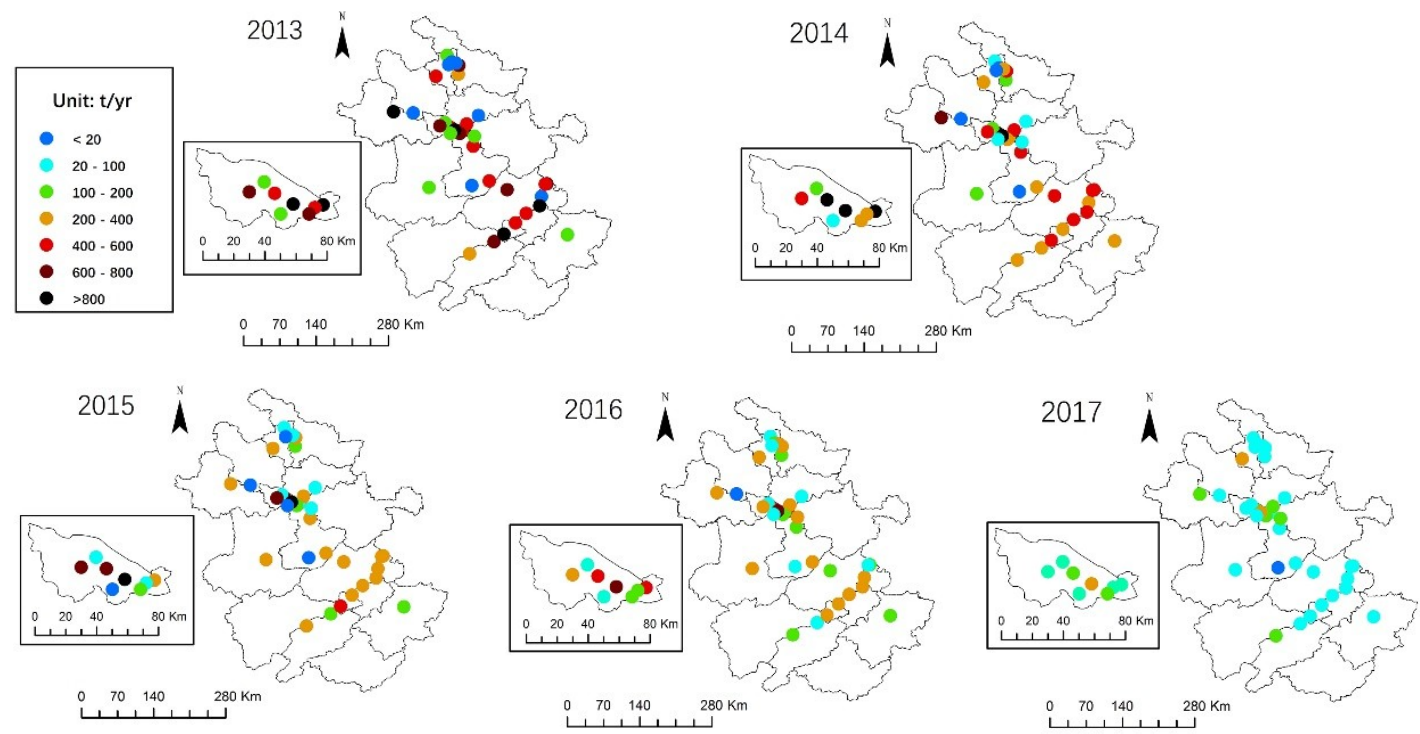

(c) PM emissions

Figure 5. Spatial distribution of (a) $\mathrm{NO}_{\mathrm{x}},(\mathbf{b}) \mathrm{SO}_{2}$ and (c) PM emissions from coal-fired power plants in Anhui Province from 2013 to 2017.

\subsection{Contribution of the Control Measures to the Reduction in $\mathrm{NO}_{x}, \mathrm{SO}_{2}$ and PM Emissions}

Figure 6 shows the contribution of the stringent control measures to the reduction $\left(\% \Delta_{t}\right)$ in $\mathrm{NO}_{\mathrm{x}}$ $\mathrm{SO}_{2}$ and $\mathrm{PM}$ emissions from coal-fired power plants from 2014 to 2017 . Only a $48.3 \% \mathrm{NO}_{\mathrm{x}}$ emission reduction, a $20.2 \% \mathrm{SO}_{2}$ emission reduction and a $26.6 \% \mathrm{PM}$ emission reduction were achieved in 2014 (compared with a 2013 baseline). However, the $\% \Delta_{t}$ in $\mathrm{NO}_{\mathrm{x}}, \mathrm{SO}_{2}$ and $\mathrm{PM}$ emissions significantly increased from 2015 and their emissions experienced a reduction of up to $81.9 \%$ for $\mathrm{NO}_{\mathrm{x}}$ and $74.2 \%$ for $\mathrm{SO}_{2}$ and $83.9 \%$ for $\mathrm{PM}$ in 2017. Overall, the $\mathrm{NO}_{\mathrm{x}}$ emissions in Anhui had greater mitigation potential than $\mathrm{SO}_{2}$ emissions due to the extensive application and improved efficiency of SCR, which were similar to the $\mathrm{NO}_{\mathrm{x}}$ emissions in Shandong [15].

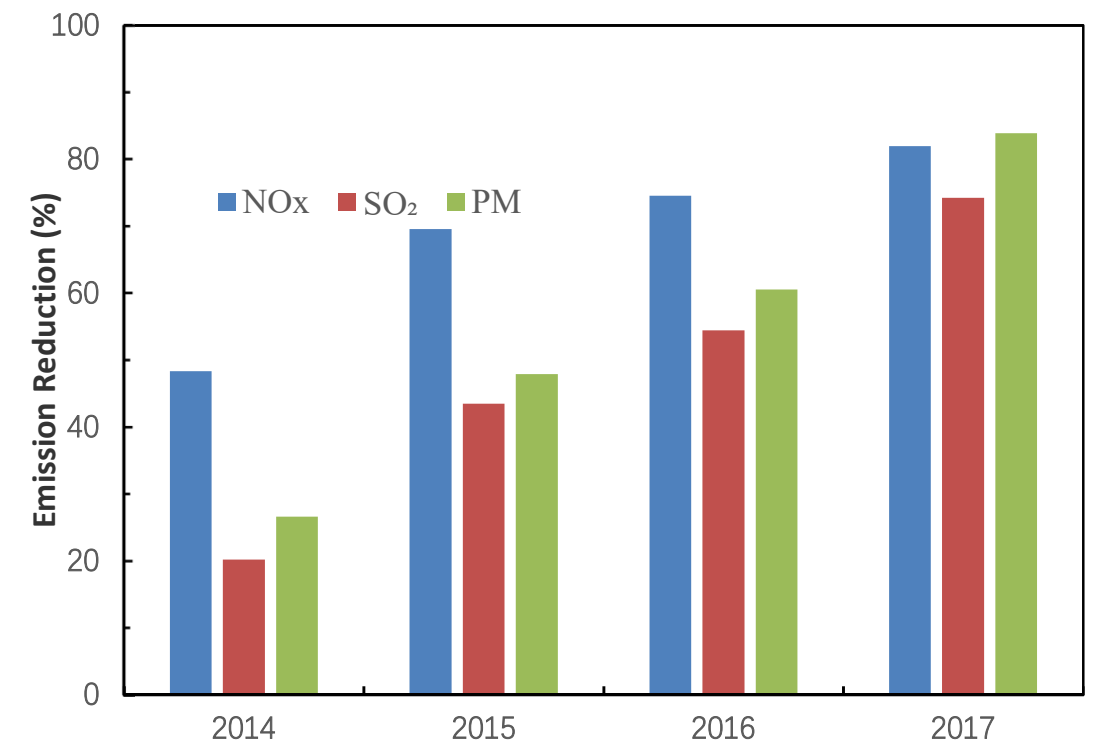

Figure 6. The contribution of the control measures to the reduction in $\mathrm{NO}_{\mathrm{x}}, \mathrm{SO}_{2}$ and $\mathrm{PM}$ emissions from 2014 to 2017 in Anhui relative to the baseline emissions for 2013. 
Numerous scholars have estimated the atmospheric pollutant emissions from coal-fired power plants in other provinces, such as Shandong Province $[15,24,42,43]$. However, there is still a lack of an emission inventory of the coal-fired power plants in Anhui Province. In addition, previous studies focused on the pollutant emissions from power plants before 2013 and only contained projections for the future emissions [25,44]. During the 11th FYP period (2006-2010), the Chinese government had introduced a series of air pollutant emission standards for coal-fired power plants and the installation of PM-removing and desulphurization devices was completed in each power plant $[29,30]$. During the 12th FYP (2011-2015), the stringent regional policy and the nationwide controls on $\mathrm{NO}_{\mathrm{x}}$ emissions were implemented along with the $\mathrm{SO}_{2}$ and PM emissions due to the application of ESP (electrostatic precipitator), FGD (flue gas desulfurization), LNBs technology (low-NOX burner) and SCR (selective catalytic reduction) [8]. Their emissions decreased from $116.9 \mathrm{kt}, 49.4 \mathrm{kt}$ and $16.0 \mathrm{kt}$ in 2013 to $24.5 \mathrm{kt}$ $\mathrm{NO}_{\mathrm{x}}, 14.8 \mathrm{kt} \mathrm{SO}$ and $3.0 \mathrm{kt} \mathrm{PM}$ in 2017. Compared with the previous literature scenario analysis for future emissions, the air pollutant emissions from coal-fired power plants greatly decreased due to the high-efficiency control technology scenario $[2,17]$. Therefore, an updated emission inventory of the coal-fired power plants is essential because coal-fired emissions have changed significantly in Anhui during the latest decade. Our results indicated that coal-fired emissions could be controlled with the application of desulfurization, denitration and dust-removing devices.

\section{Conclusions}

In this study, we developed an emission inventory based on CEMS data from the coal-fired power sector in Anhui Province during the period from 2013 to 2017. The $\mathrm{NO}_{\mathrm{x}}, \mathrm{SO}_{2}$ and $\mathrm{PM}$ emissions from coal-fired power plants had decreased from $116.9 \mathrm{kt}, 49.4 \mathrm{kt}$ and $16.0 \mathrm{kt}$ in 2013 to $24.5 \mathrm{kt}, 14.8 \mathrm{kt}$ and $3.0 \mathrm{kt}$, respectively, in 2017 . The emission reductions of approximately $79.0 \%, 70.1 \%$ and $81.2 \%$ were achieved in 2017 compared with a 2013 baseline, respectively, due to the application of high-efficiency emission control measures, including the desulfurization, denitration and dust-removing devices and selective catalytic reduction (SCR). The coal-fired units ( $\geq 600 \mathrm{MW}$ ) generated $80.6 \%$ of the power but emitted $70.5 \%$ of the $\mathrm{NO}_{\mathrm{x}}, 70.1 \%$ of the $\mathrm{SO}_{2}$ and $71.9 \%$ of the $\mathrm{PM}$ due to the lower coal consumption, higher desulfurization, denitration and dust-removing efficiency compared to low units. The peaks for seasonal $\mathrm{NO}_{\mathrm{x}}, \mathrm{SO}_{2}$ and $\mathrm{PM}$ emissions were concentrated in summer and winter and their emissions were positively correlated with the power generation. Northeastern coal-rich cities, such as Huainan and Huaibei, and southeastern cities, such as Tongling, Wuhu and Maanshan, are the major emission contributors in Anhui. Huainan had highest emission with about $26 \% \sim 40 \%$ of total emission. The $\mathrm{NO}_{\mathrm{x}}$ and $\mathrm{SO}_{2}$ emissions decreased by $68 \%$ and $41 \%$, respectively, from 2013 to 2015 . Compared with other Chinese provinces, the emission showed a larger reduction in Anhui due to the higher proportion $(71.2 \%)$ of the installed units of $\geq 600 \mathrm{MW}$. Our results indicated that the control measures, including the desulfurization, denitration and dust-removing devices and selective catalytic reduction (SCR), greatly decreased $\mathrm{NO}_{\mathrm{x}}, \mathrm{SO}_{2}$ and $\mathrm{PM}$ emissions.

Supplementary Materials: The following are available online at http:/ /www.mdpi.com/2073-4433/10/1/35/s1, Table S1: Changes of installed units and power generation from coal-fired power plants in Anhui from 2012 to 2017, Table S2: An overview of CEMS execution standards and test basis in Anhui coal-fired power plants.

Author Contributions: Conceptualization, D.M.; Data curation, J.H.; Formal analysis, R.Z.; Methodology, H.D. and B.S.; Software, H.D.; Validation, H.D. and D.M.; Writing—original draft, H.D.; Writing—review \& editing, D.M. and R.Z.

Funding: This research was funded by the National Natural Science Foundation of China (Grant No. 41576181; 41776190), and the funding of State Grid Anhui Electric Power Research Institute.

Acknowledgments: The authors gratefully acknowledge discussions with Fei Liu (NASA). We acknowledge the helpful comments from the referees that improved this manuscript.

Conflicts of Interest: There are no conflict of interest to declare. 


\section{References}

1. Su, S.; Fang, X.; Zhao, J.; Hu, J. Spatiotemporal characteristics of consumption based $\mathrm{CO}_{2}$ emissions from China's power sector. Resour. Conserv. Recycl. 2017, 121, 156-163. [CrossRef]

2. Zhao, Y.; Wang, S.; Duan, L.; Lei, Y.; Cao, P.; Hao, J. Primary air pollutant emissions of coal-fired power plants in China: Current status and future prediction. Atmos. Environ. 2008, 42, 8442-8452. [CrossRef]

3. Zhao, Y.; Wang, S.; Nielsen, C.P.; Li, X.; Hao, J. Establishment of a database of emission factors for atmospheric pollutants from Chinese coal-fired power plants. Atmos. Environ. 2010, 44, 1515-1523. [CrossRef]

4. Wang, S.; Xing, J.; Chatani, S.; Hao, J.; Klimont, Z.; Cofala, J.; Amann, M. Verification of anthropogenic emissions of China by satellite and ground observations. Atmos. Environ. 2011, 45, 6347-6358. [CrossRef]

5. Wang, S.; Hao, J. Air quality management in China: Issues, challenges, and options. J. Environ. Sci. 2012, 24, 2-13. [CrossRef]

6. CEC. Annual Development Report of China's Power Industry 2014; China Electricity Council: Beijing, China, 2013-2017. (In Chinese)

7. Keohane, N.O.; Revesz, R.L.; Stavins, R.N. The Choice of Regulatory Instruments in Environmental Policy. Harv. Environ. Law Rev. 1998, 22, 313-367.

8. Schreifels, J.J.; Fu, Y.; Wilson, E.J. Sulfur dioxide control in China: Policy evolution during the 10th and 11th Five-year Plans and lessons for the future. Energy Policy 2012, 48, 779-789. [CrossRef]

9. Liu, X.; Wen, Z. Best available techniques and pollution control: A case study on China's thermal power industry. J. Clean. Prod. 2012, 23, 113-121. [CrossRef]

10. Price, L.; Levine, M.D.; Zhou, N.; Fridley, D.; Aden, N.; Lu, H.; McNeil, M.; Zheng, N.; Qin, Y.; Yowargana, P. Assessment of China's energy-saving and emission-reduction accomplishments and opportunities during the 11th Five Year Plan. Energy Policy 2011, 39, 2165-2178. [CrossRef]

11. Zhang, X.; Schreifels, J. Continuous emission monitoring systems at power plants in China: Improving $\mathrm{SO}_{2}$ emission measurement. Energy Policy 2011, 39, 7432-7438. [CrossRef]

12. Wang, Q.; Chen, Y. Energy saving and emission reduction revolutionizing China's environmental protection. Renew. Sustain. Energy Rev. 2010, 14, 535-539. [CrossRef]

13. Wang, S.; Xing, J.; Zhao, B.; Jang, C.; Hao, J. Effectiveness of national air pollution control policies on the air quality in metropolitan areas of China. J. Environ. Sci. 2014, 26, 13-22. [CrossRef]

14. Zhang, M.; Song, Y.; Cai, X.; Zhou, J. Economic assessment of the health effects related to particulate matter pollution in 111 Chinese cities by using economic burden of disease analysis. J. Environ. Manag. 2008, 88, 947-954. [CrossRef] [PubMed]

15. Xiong, T.; Jiang, W.; Gao, W. Current status and prediction of major atmospheric emissions from coal-fired power plants in Shandong Province, China. Atmos. Environ. 2016, 124, 46-52. [CrossRef]

16. Wang, S.W.; Zhang, Q.; Streets, D.G.; He, K.B.; Martin, R.V.; Lamsal, L.N.; Chen, D.; Lei, Y.; Lu, Z. Growth in $\mathrm{NO}_{\mathrm{x}}$ emissions from power plants in China: Bottom-up estimates and satellite observations. Atmos. Chem. Phys. 2012, 12, 4429-4447. [CrossRef]

17. Tian, H.; Liu, K.; Hao, J.; Wang, Y.; Gao, J.; Qiu, P.; Zhu, C. Nitrogen oxides emissions from thermal power plants in China: Current status and future predictions. Environ. Sci. Technol. 2013, 47, 11350-11357. [CrossRef] [PubMed]

18. Liu, X.; Lin, B.; Zhang, Y. Sulfur dioxide emission reduction of power plants in China: Current policies and implications. J. Clean. Prod. 2016, 113, 133-143. [CrossRef]

19. Li, C.; Zhang, Q.; Krotkov, N.A.; Streets, D.G.; He, K.; Tsay, S.-C.; Gleason, J.F. Recent large reduction in sulfur dioxide emissions from Chinese power plants observed by the Ozone Monitoring Instrument. Geophys. Res. Lett. 2010, 37. [CrossRef]

20. Frost, G.J.; McKeen, S.A.; Trainer, M.; Ryerson, T.B.; Neuman, J.A.; Roberts, J.M.; Swanson, A.; Holloway, J.S.; Sueper, D.T.; Fortin, T.; et al. Effects of changing power plant $\mathrm{NO}_{\mathrm{x}}$ emissions on ozone in the eastern United States: Proof of concept. J. Geophys. Res. 2006, 111, D12306. [CrossRef]

21. Peischl, J.; Ryerson, T.B.; Holloway, J.S.; Parrish, D.D.; Trainer, M.; Frost, G.J.; Aikin, K.C.; Brown, S.S.; Dubé, W.P.; Stark, H.; et al. A top-down analysis of emissions from selected Texas power plants during TexAQS 2000 and 2006. J. Geophys. Res. Atmos. 2010, 115. [CrossRef]

22. Kim, S.-W.; Heckel, A.; McKeen, S.A.; Frost, G.J.; Hsie, E.-Y.; Trainer, M.K.; Richter, A.; Burrows, J.P.; Peckham, S.E.; Grell, G.A. Satellite-observed U.S. power plant $\mathrm{NO}_{\mathrm{x}}$ emission reductions and their impact on air quality. Geophys. Res. Lett. 2006, 33, L22812. [CrossRef] 
23. Pétron, G.; Tans, P.; Frost, G.; Chao, D.; Trainer, M. High-resolution emissions of $\mathrm{CO}_{2}$ from power generation in the USA. J. Geophys. Res. Biogeosci. 2008, 113. [CrossRef]

24. Lu, Z.; Streets, D.G.; Zhang, Q.; Wang, S.; Carmichael, G.R.; Cheng, Y.F.; Wei, C.; Chin, M.; Diehl, T.; Tan, Q. Sulfur dioxide emissions in China and sulfur trends in East Asia since 2000. Atmos. Chem. Phys. 2010, 10, 6311-6331. [CrossRef]

25. Liu, F.; Zhang, Q.; Tong, D.; Zheng, B.; Li, M.; Huo, H.; He, K.B. High-resolution inventory of technologies, activities, and emissions of coal-fired power plants in China from 1990 to 2010. Atmos. Chem. Phys. 2015, 15, 13299-13317. [CrossRef]

26. Wang, S.; Streets, D.G.; Zhang, Q.; He, K.; Chen, D.; Kang, S.; Lu, Z.; Wang, Y. Satellite detection and model verification of $\mathrm{NO}_{x}$ emissions from power plants in Northern China. Environ. Res. Lett. 2010, 5, 044007. [CrossRef]

27. Zhang, X.; Wang, X.Y.; Bai, Z.P.; Han, B. Co-benefits of integrating $\mathrm{PM}_{10}$ and $\mathrm{CO}_{2}$ reduction in an electricity industry in Tianjin, China. Aerosol Air Qual. Res. 2013, 13, 756-770. [CrossRef]

28. Cai, W.; Wang, C.; Wang, K.; Zhang, Y.; Chen, J. Scenario analysis on $\mathrm{CO}_{2}$ emissions reduction potential in China's electricity sector. Energy Policy 2007, 35, 6445-6456. [CrossRef]

29. $\mathrm{Xu}, \mathrm{Y}$. The use of a goal for $\mathrm{SO}_{2}$ mitigation planning and management in China's 11th Five-Year Plan. J. Environ. Plan. Manag. 2011, 54, 769-783. [CrossRef]

30. $\mathrm{Xu}, \mathrm{Y}$. Improvements in the Operation of $\mathrm{SO}_{2}$ Scrubbers in China's Coal Power Plants. Environ. Sci. Technol. 2011, 45, 380-385. [CrossRef] [PubMed]

31. Schakenbach, J.; Vollaro, R.; Forte, R. Fundamentals of Successful Monitoring, Reporting, and Verification under a Cap-and-Trade Program. J. Air Waste Manag. Assoc. 2006, 56, 1576-1583. [CrossRef] [PubMed]

32. US EPA. CEMS Field Audit Manual; Part 75; United States Environmental Protection Agency (US EPA): Washington, DC, USA, 2003.

33. Xu, R.; Mei, Z.M.; Zhao, M.Q.; He, H.X. Inquisition to Several Issues in Performance Test of SCR Flue Gas Denitration System. Adv. Mater. Res. 2012, 610-613, 1610-1615. [CrossRef]

34. Sun, Y. Study on Emission Inventory and Uncertainty Assessment of Multi-Pollutants from Coal-Fired Power Plants. Master's Thesis, Zhejiang University, Hangzhou, China, 2015.

35. Jin, W.Q. Power Plant Boiler; China Waterpower Press: Beijing, China, 2001.

36. Wang, J.; Wang, Z.G.; Zhao, B.; Wang, S.X.; Hao, J.M. Cost-effectiveness analysis of multi-pollutant emission reduction in power sector of China. Res. Environ. Sci. 2014, 27, 1314-1322.

37. Elser, M.; Huang, R.-J.; Wolf, R.; Slowik, J.G.; Wang, Q.; Canonaco, F.; Li, G.; Bozzetti, C.; Daellenbach, K.R.; Huang, Y.; et al. New insights into $\mathrm{PM}_{2.5}$ chemical composition and sources in two major cities in China during extreme haze events using aerosol mass spectrometry. Atmos. Chem. Phys. 2016, 16, 3207-3225. [CrossRef]

38. Zheng, M.; Salmon, L.G.; Schauer, J.J.; Zeng, L.; Kiang, C.S.; Zhang, Y.; Cass, G.R. Seasonal trends in PM 2.5 source contributions in Beijing, China. Atmos. Environ. 2005, 39, 3967-3976. [CrossRef]

39. Huang, R.-J.; Zhang, Y.; Bozzetti, C.; Ho, K.-F.; Cao, J.-J.; Han, Y.; Daellenbach, K.R.; Slowik, J.G.; Platt, S.M.; Canonaco, F.; et al. High secondary aerosol contribution to particulate pollution during haze events in China. Nature 2014, 514, 218-222. [CrossRef] [PubMed]

40. Liu, D.; Yao, Y.; Tang, D.; Tang, S.; Che, Y.; Huang, W. Coal reservoir characteristics and coalbed methane resource assessment in Huainan and Huaibei coalfields, Southern North China. Int. J. Coal Geol. 2009, 79, 97-112. [CrossRef]

41. Tian, H.; Wang, Y.; Xue, Z.; Qu, Y.; Chai, F.; Hao, J. Atmospheric emissions estimation of Hg, As, and Se from coal-fired power plants in China, 2007. Sci. Total Environ. 2011, 409, 3078-3081. [CrossRef]

42. Chen, L.; Sun, Y.; Wu, X.; Zhang, Y.; Zheng, C.; Gao, X.; Cen, K. Unit-based emission inventory and uncertainty assessment of coal-fired power plants. Atmos. Environ. 2014, 99, 527-535. [CrossRef]

43. Wu, Y.; Streets, D.G.; Wang, S.X.; Hao, J.M. Uncertainties in estimating mercury emissions from coal-fired power plants in China. Atmos. Chem. Phys. 2010, 10, 2937-2946. [CrossRef]

44. Zhao, Y.; Zhang, J.; Nielsen, C.P. The effects of recent control policies on trends in emissions of anthropogenic atmospheric pollutants and $\mathrm{CO}_{2}$ in China. Atmos. Chem. Phys. 2013, 13, 487-508. [CrossRef]

(c) 2019 by the authors. Licensee MDPI, Basel, Switzerland. This article is an open access article distributed under the terms and conditions of the Creative Commons Attribution (CC BY) license (http://creativecommons.org/licenses/by/4.0/). 